\title{
HUBUNGAN PENGEMBANGAN DIRI DENGAN LOYALITAS KINERJA GURU SEKOLAH DASAR
}

\author{
Puji Astuti \\ e-mail: astuti_fuji22@yahoo.com \\ Sekolah Tinggi Ilmu Kesehatan (STIK) Bina Husada Palembang
}

Jalan Syech Abdul Somad No. 28 Kel 22 Ilir Palembang Sumatera Selatan

\begin{abstract}
Abstrak: Penelitian ini bertujuan untuk menentukan hubungan antara pengembangan diri dan loyalitas kinerja guru. Penelitian ini dilaksanakan di SDN 2 Margomulyo, OKU Timur dengan subyek penelitian berjumlah 25 orang guru. Penelitian ini menggunakan dan mengimplementasikan desain cross sectional sejak April hingga Agustus 2018. Teknik analisis data menggunakan statistik non parametrik. Hasil menunjukkan bahwa tidak ada hubungan yang signifkan antara pengembangan diri dengan loyalitas kinerja $(0,877>0,05)$. Berdasarkan hasil tersebut, implikasi dan saran dibahas lebih lanjut.
\end{abstract}

Kata-kata Kunci: Pengembangan diri, loyalitas kinerja, guru

\section{THE CORRELATION BETWEEN SELF-DEVELOPMENT AND THE LOYALTY OF ELEMENTARY SCHOOL TEACHER PERFORMANCE}

\begin{abstract}
This research aims to determine the correlation between self-development and teacher performance loyalty. This study was conducted in SDN 2 Margomulyo, OKU Timur with a total of 25 teachers. A cross-sectional design was used and implemented from April to August 2018. The data analysis technique used was nonparametric statistics. The results showed that there was no signifcant relationship between self-development with performance loyalty $(0,877>0,05)$. Based on this result, implications and recommendations are discussed further.
\end{abstract}

Keywords: Self development, performance loyalty, teacher.

\section{PENDAHULUAN}

Kinerja Guru pada dasarnya merupakan kinerja atau unjuk kerja yang dilakukan oleh guru dalam melaksanakan tugasnya sebagai pendidik. Smith dalam (Mulyasa, 2005) menyatakan bahwa kinerja adalah "...output drive from processes, human or otherwise". Kinerja merupakan hasil atau keluaran dari suatu proses. Dikatakan lebih lanjut oleh Mulyasa bahwa kinerja atau performance dapat diartikan sebagai prestasi kerja, pelaksanaan kerja, pencapaian kerja, hasil-hasil kerja atau unjuk kerja.

Kualitas kinerja guru akan sangat menentukan pada kualitas hasil pendidikan, karena guru merupakan pihak yang paling banyak bersentuhan langsung dengan siswa dalam proses pendidikan/ pembelajaran di lembaga pendidikan Sekolah. Guru pada dasarnya merupakan salah satu komponen dalam proses pembelajaran yang ikut berperan dalam usaha pembentukan sumber daya manusia yang potensial dibidang pembangunan. Sebagai komponen dalam bidang kependidikan, seorang guru harus berperan serta secara aktif dan menempatkan kedudukannya sebagai tenaga profesional, sesuai dengan tuntutan masyarakat yang semakin berkembang, sehingga ia dituntut memiliki integritas, loyalitas, dedikasi, dan responsibility untuk mewujudkan dirinya menjadi guru profesional. 
Dalam arti khusus, guru tidak semata-mata sebagai "pengajar" yang melaksanakan transfer of knowledge, tapi juga sebagai "pendidik" yang berkewajiban melaksanakan transfer of values, sekaligus sebagai "pelatih" yang melakukan transfer of skill, dan "pembimbing" yang memberikan pengarahan dan menuntun siswa dalam belajar (Isjoni, 2007).

Sekolah sebagai organisasi, di dalamnya terhimpun unsur-unsur yang masing-masing baik secara perseorangan maupun kelompok melakukan komunikasi interpersonal untuk mencapai tujuan. Untuk mencapai tujuan tersebut, lembanga sekolah tidak hanya dituntut untuk mempunyai struktur organisasi yang baik, sarana dan prasarana yang memadai, akan tetapi juga diperlukan adanya tenaga-tenaga yang handal dalam penyelenggaraan pendidikan. Hal ini sejalan dengan apa yang dikemukakan oleh (Gomes, 2006) tugas manajemen sumber daya manusia berkaitan dengan upaya mengelola unsur manusia dengan segala potensi yang dimilikinya harus dilakukan seefektif mungkin sehingga dapat diperoleh sumber daya manusia yang puas (satisfied) dan memuaskan (satisfactory) bagi organisasi. Salah satu sumber daya yang penting dalam penyelenggaraan pendidikan sebagai pelaksana administrasi akademik adalah guru.

Dalam mencapai keberhasilan suatu penyelenggaraan pendidikan dibutuhkan guru yang berorientasi kepada loyalitas kinerja. (Jusuf, 2010) berpendapat bahwa loyalitas merupakan suatu sikap yang timbul sebagai akibat keinginan untuk setia dan berbakti baik itu pada pekerjaannya kelompok, atasan, maupun pada tempat kerjanya yang menyebabkan seseorang rela berkorban demi memuaskan pihak lain atau masyarakat.

Loyalitas kerja guru terhadap pekerjaan merupakan keyakinan seorang guru mengenai pekerjaan yang diembannya, yang disertai adanya perasaan tertentu, dan memberikan dasar kepada guru tersebut untuk membuat respons atau berperilaku dalam cara tertentu sesuai pilihannya. Loyalitas kerja guru terhadap pekerjaan mempengaruhi tindakan guru tersebut dalam menjalankan aktivitas kerjanya. Bilamana seorang guru memiliki loyalitas kerja yang tinggi terhadap pekerjaannya, maka sudah barang tentu guru akan menjalankan fungsi dan kedudukannya sebagai tenaga pengajar dan pendidik di sekolah dengan penuh rasa tanggung jawab. Demikian pula sebaliknya seorang guru yang memiliki loyalitas rendah terhadap pekerjaannya, pastilah dia hanya menjalankan fungsi dan kedudukannya sebatas rutinitas belaka. Untuk itu amatlah perlu kiranya dibentuk loyalitas guru yang tinggi terhadap pekerjaan, mengingat peran guru dalam lingkungan pendidikan dalam hal ini sekolah amatlah sentral.

Oleh karenanya, dalam usaha mengembangkan diri pun dipengaruhi berbagai faktor baik dari dalam maupun dari luar manusia itu sendiri. Kemampuan seseorang untuk mengembangkan dirinya, mengoptimalkan potensi yang dimilikinya, berbeda-beda dan seringkali kendala juga datang dari diri sendiri. Lebih lanjut dinyatakan bahwa guru merupakan komponen yang berpengaruh dalam peningkatan mutu pendidikan di sekolah. Hal ini menunjukkan bahwa kemampuan atau kompetensi profesional dari seorang guru sangat menentukan mutu pendidikan. Ditinjau dari segi loyalitas guru, pada saat sekarang ini banyak guru yang kurang memahami makna mendidik yang kenyataannya kesadaran untuk memajukan satuan pendidikan tidak berjalan semestinya, contohnya seperti tidak adanya disiplin waktu dan ketidaksetiaan dalam menjalankan tugasnya. Guru sekarang hanya menjalankan tugasnya hanya sebatas untuk menggugurkan kewajibannya, tanpa adanya komitmen penuh untuk mendidik siswa secara utuh dan menyeluruh baik jasmani maupun rohani. Karena kurangnya rasa memiliki terhadap tingkat satuan pendidikan, maka tujuan terciptanya hasil pembelajaran yang baik akan sulit tercapai. Sehingga dapat dipahami betapa pentingnya upaya peningkatan loyalitas kerja agar kinerja guru dapat menuai prestasi kerja.

Permasalahan di atas sejalan dengan beberapa hasil penelitian (Wicaksono, 2013) tentang Hubungan Pengembangan Karir dan Pemberian Insentif terhadap Loyalitas Kinerja Guru bahwa terdapat hubungan yang kuat antara pengembangan terhadap loyalitas kinerja guru di SMP Tri Mulya Semarang karena nilai $r$ hitung sebesar 0,799.

Hasil penelitian A. Hanin, AK. Djaelani, dan MK. ABS, 2018) tentang Pengaruh Pengembangan Karir dan Pemberian Insentif terhadap Loyalitas Karyawan Radar Bromo Probolinggo (Jawa Pos Grup) bahwa pengembangan karir berpengaruh parsial terhadap loyalitas karyawan, pemberian insentif juga memiliki pengaruh parsial terhadap loyalitas karyawan. Dan hasil dari pengembangan karir dan pemberian insentif berpengaruh simultan terhadap loyalitas karyawan.

Sebagaimana hasil pengamatan yang peneliti lalukan diSDN 2 Margomulyo OKU Timur merupakan institusi yang sedang berkembang dan membutuhkan sumber daya manusia yang dapat memberikan kemajuan dan pelayanan yang maksimal kepada para 
siswa. Untuk itu loyalitas seorang guru merupakan hal yang terpenting, tetapi keadaan yang ada bahwa loyalitas kinerja guru SDN 2 Margomulyo OKU Timur belum tampak dan kurang berjalan maksimal. Hal ini banyak penyebabnya salah satunya masih rendahnya usaha pengembangan diri guru dan kurangnya kerjasama antar guru dalam menyelesaikan tugastugas disekolah.

Selain berdasarkan pada hasil pengamatan langsung dan hasil penelitian yang relevan, informasi yang disampaikan oleh kepala SDN 2 Margomulyo OKU Timur Bapak Giman, S.Pd.SD bahwa: “loyalitas kinerja guru memang masih sangat rendah, hal ini sering terlihat ada guru yang datang telat dan pulang lebih cepat, mereka kurang memperhatikan apakah pekerjaan yang ditinggalkan harus diselesaikan dengan cepat atau memang perlu didiskusikan dengan rekannya bahkan atasannya". Mengingat pentingnya keberadaan para guru dalam rangka peningkatan pelayanan yang berkualitas dan profesional kepada para siswa, maka berbagai upaya telah ditempuh oleh pihak sekolah agar loyalitas kinerja guru lebih baik. Upaya ini besar artinya bukan saja bagi guru sendiri, tetapi juga terhadap pemenuhan kepentingan para siswa khususnya dan umumnya seluruh civitas akademika dan masyarakat luas.

Begitu urgennya permasalahan peningkatan loyalitas kinerja guru tersebut di atas, maka perlu dilakukan penelitian yang intensif dan memadai guna mendapatkan informasi berkenaan dengan berbagai hal yang memberikan kontribusi terhadap loyalitas kinerja guru di SDN 2 Margomulyo OKU Timur. Dalam hal ini faktor yang diduga dominan ada hubungan dengan loyalitas kinerja guru yakni faktor pengembangan diri dari guru. Sehingga dalam permasalahan ini maka peneliti tertarik untuk melakukan penelitian tentang hubungan pengembangan diri dengan loyalitas kinerja guru SDN 2 Margomulyo OKU Timur tahun 2018.

Tujuan penelitian ini adalah untuk mengetahui hubungan pengembangan diri guru dengan loyalitas kinerja guru SDN 2 Margomulyo OKU Timur. Kontribusi penelitian diharapkan berguna bagi: (1) Institusi pendidikan, kiranya dapat dijadikan sebagai bahan pertimbangan dan masukan/sumber informasi dalam pengambilan kebijakan yang berkaitan dengan pengembangan dan pembinaan guru, (2) Guru sebagai gambaran pentingnya mengembangkan diri secara maksimal dan bersikap positif terhadap loyalitas kinerja, (3) Peneliti lainnya sebagai refrensi dalam melakukan penelitian-penelitian lain dan selanjutnya.

\section{METODE PENELITIAN}

Desain penelitian ini menggunakan desain penelitian Cross Sectional. Notoatmodjo (2012), Cross Sectional merupakan jenis penelitian yang menekankan waktu pengukuran/observasi data variabel bebas dan tergantung hanya satu kali pada satu saat. Penelitian ini dilaksanakan di SDN 2 Margomulyo OKU Timur pada 09 April s.d 02 Agustus 2018. Populasi dalam penelitian ini yaitu 25 orang guru. Penentuan sampel dalam penelitian ini dilakukan dengan jenis Non Probability Sampling jenis sampel ini tidak dipilih secara acak. Teknik Non Probability Sampling yang dipilih yaitu dengan Sampling jenuh (sensus) yaitu metode penarikan sampel bila semua anggota populasi dijadikan sebagai sampel. Sugiyono (2017) bahwa: "Sampling jenuh adalah teknik penentuan sampel bila semua anggota populasi digunakan sebagai sampel

Pengumpulan data menggunakan kuesioner (angket) model skala likert. dengan lima alternatif jawaban yakni:

Tabel 1.

Skor Alternatif Jawaban Angket

\begin{tabular}{ccc}
\hline Alternatif Jawaban & Positif (Favorable) & Negatif (Unfavorable) \\
\hline Selalu & 5 & 1 \\
Sering & 4 & 2 \\
Kadang-Kadang & 3 & 3 \\
Jarang & 2 & 4 \\
Tidak Pernah & 1 & 5 \\
\hline
\end{tabular}

Hasil uji validitas dan reliabilitasnya yaitu instrumen pengembangan diri $(0,952<0,001)$ dan instrumen loyalitas kinerja $(0,890<0,001)$ yang artinya kedua intrumen tersebut adalah valid dan reliabel.

Selanjutnya teknik analisis data yang digunakan meliputi; (1) analisis univariat dilakukan terhadap tiap variabel dari hasil penelitian yang hanya menghasilkan distribusi dan tingkat ketercapaian ukur masingmasing variabel. Untuk dapat menetahui tingkat pencapaian responden dari instrumen penelitian yang digunakan, peneliti mengacu kepada rumus dan skala nilai dari Sudjana (2005), sebagai berikut:

Tabel 2.

Skor Alternatif Jawaban Angket

\begin{tabular}{lcc}
\hline No & Klasifikasi & Kategori \\
\hline 1 & Sangat baik & $90-100 \%$ \\
2 & Baik & $80-89 \%$ \\
3 & Cukup & $65-79 \%$ \\
4 & Kurang baik & $55-64 \%$ \\
5 & Tidak baik & $0-54 \%$ \\
\hline
\end{tabular}


(2) analisis bivariat dihitung menggunakan statistik nonparametrik (korelasi spearman rank). Statistik nonparametrik digunakan untuk melengkapi metode statistik parametrik (Singgih, 2014). Kelebihan dan kekurangan statistik nonparametrik adalah dapat digunakannya metode tersebut pada data yang tidak bisa diproses dengan prosedur parametrik. Jadi, pada bentuk data apapun, jumlah data berapapun, prosedur parametrik bisa digunakan.

\section{HASIL DAN PEMBAHASAN}

Desain penelitian ini menggunakan desain peneBerdasarkan butir-butir pernyataan variabel pengembangan diri yang berjumlah 30 butir pernyataan, maka skor minimum yang mungkin diperoleh 30 dan skor maksimum adalah 150. Hasil dari data yang diperoleh skor terendah adalah 68 dan yang tertinggi adalah 102. Rata-rata 88,68 simpangan baku 7,064, median 89,00 dan modus 89,00 . Sebaran data ini menunjukkan bahwa skor ratarata, simpangan baku, median dan modus tidak jauh berbeda, hal ini menunjukkan bahwa sebaran data cenderung berdistribusi normal.

Sesuai dengan hasil perhitungan statistik dasar yang telah dilakukan, data diklasifikasikan dalam tujuh interval kelas.

Untuk memperoleh gambaran yang jelas tentang distribusi skor variabel pengembangan diri dapat dilihat pada tabel dan gambar histogram sebagai berikut.

Tabel 3.

Distribusi Frekuensi Skor Pengembangan Diri

\begin{tabular}{ccc}
\hline Skor Interval & Frekuensi Absolut & Frekuensi Relatif (\%) \\
\hline $98-102$ & 2 & 8 \\
$93-97$ & 5 & 20 \\
$88-92$ & 10 & 40 \\
$83-87$ & 4 & 16 \\
$78-82$ & 1 & 4 \\
$73-77$ & 1 & 4 \\
$68-72$ & 1 & 4 \\
\hline Jumlah & 25 & $100 \%$ \\
\hline
\end{tabular}

Dari data yang diperoleh pada distribusi frekuensi skor pengembangan diri rata-rata tingkat pencapaian skor pengembangan diri guru sebesar 59,12\%, sehingga dengan melihat kriteria yang dikemukakan oleh Sudjana (2005) berarti pengembangan diri guru berada pada kategori kurang baik. Artinya pengembangan diri guru masih kurang.

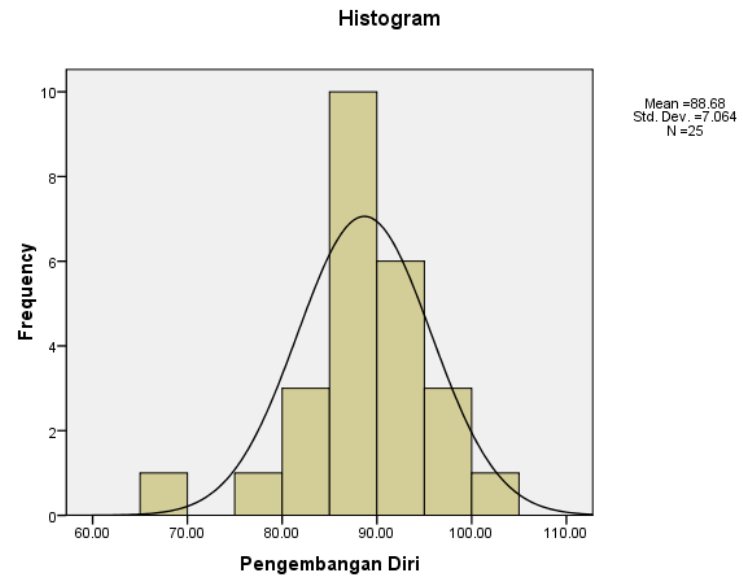

Gambar 1.Histogram Variabel Pengembangan Diri

Sedangkan berdasarkan butir-butir pernyataan variabel loyalitas kinerja guru yang berjumlah 30 butir, maka skor minimal yang mungkin diperoleh 30 dan skor maksimal adalah 150. Hasil dari data yang diperoleh skor terendah adalah 76 dan yang tertinggi adalah 106 . Rata-rata 90,60, simpangan baku 6,493, median 90,00, dan modus 86,00. Sebaran data ini menunjukkan bahwa skor rata-rata, median dan modus tidak jauh berbeda, hal ini menunjukkan bahwa sebaran data cenderung berdistribusi normal.

Untuk memperoleh gambaran yang jelas tentang distribusi skor variabel loyalitas kinerja guru dapat dilihat pada tabel dan gambar histogram sebagai berikut.

Tabel 4.

Distribusi Frekuensi Skor Loyalitas Kinerja Guru

\begin{tabular}{ccc}
\hline Skor Interval & Frekuensi Absolut & Frekuensi Relatif (\%) \\
\hline $101-106$ & 2 & 8 \\
$96-100$ & 3 & 12 \\
$91-95$ & 7 & 28 \\
$86-90$ & 9 & 36 \\
$81-85$ & 2 & 8 \\
$76-80$ & 2 & 8 \\
\hline Jumlah & 25 & $100 \%$ \\
\hline
\end{tabular}

Dari data distribusi frekuensi skor loyalitas kinerja guru diperoleh rata-rata tingkat pencapaian responden sebesar $60,4 \%$ sehingga dengan melihat kriteria yang dikemukakan oleh Sudjana (2005) berarti pengembangan diri guru berada pada kategori kurang baik. Artinya loyalitas kinerja guru masih kurang. 


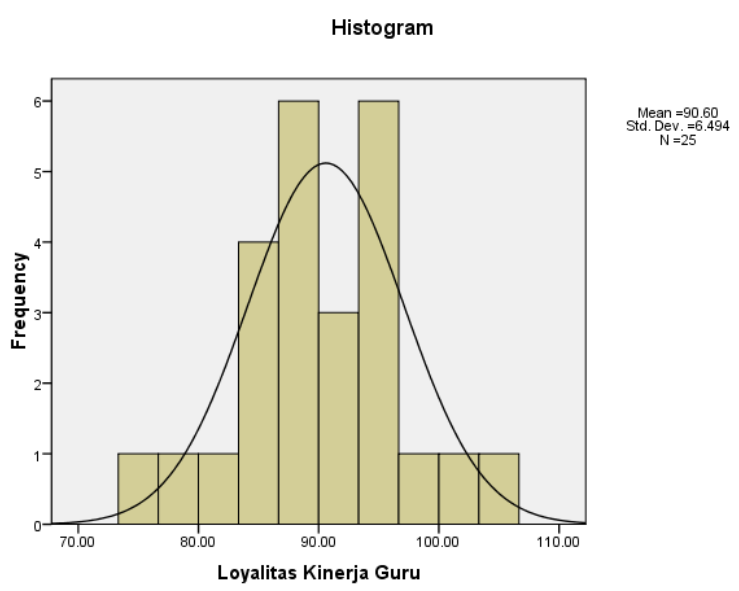

Gambar 2. Histogram Loyalitas Kinerja Guru

Untuk mengetahui hubungan antara variabel independen (pengembangan diri) dengan variabel dependen (loyalitas kinerja guru). Hipotesis yang diajukan adalah ada hubungan pengembangan diri dengan loyalitas kinerja guru SDN 2 Margomulyo OKU Timur.

Tabel 5.

Hubungan Pengembangan diri dengan Loyalitas Kinerja Guru SDN 2 Margomulyo

\begin{tabular}{|c|c|c|c|c|}
\hline \multicolumn{5}{|c|}{ Correlations } \\
\hline & & & Pengem & Loyalitas \\
\hline & & & bangan & Kinerja \\
\hline & & & Diri $(X)$ & Guru (Y) \\
\hline \multirow{8}{*}{$\begin{array}{l}\text { Spearman's } \\
\text { rho }\end{array}$} & Pengembangan & Correlation & 1.000 & -.033 \\
\hline & Diri $(X)$ & Coefficient & & \\
\hline & & Sig. (2-tailed) & . & .877 \\
\hline & & $\mathrm{N}$ & 25 & 25 \\
\hline & Loyalitas & Correlation & -.033 & 1.000 \\
\hline & Kinerja Guru & Coefficient & & \\
\hline & $(\mathrm{Y})$ & Sig. (2-tailed) & .877 & . \\
\hline & & $\mathrm{N}$ & 25 & 25 \\
\hline
\end{tabular}

Berdasarkan hasil output tabel 4 di atas, diketahui nilai signifikan atau sig. (2-tailed) sebesar 0,877, karena nilai sig. (2-tailed) 0,877 < lebih kecil dari 0,05 maka artinya ada hubungan yang signifikan (bermakna) antara variabel pengembangan diri dangan loyalitas kinerja guru SDN 2 Margomulyo OKU Timur.

\section{Pembahasan}

Temuan yang diperoleh berdasarkan rangkaian analisis data menunjukkan bahwa variabel pengembangan diri rata-rata tingkat pencapaian skor sebesar 59,12\%, dan skor loyalitas kinerja guru diperoleh rata-rata tingkat pencapaian responden sebesar $60,4 \%$, sehingga dengan melihat kriteria yang dikemukakan oleh Sudjana (1982) berarti pengembangan diri guru berada pada kategori kurang baik. Artinya pengembangan diri dan loyalitas kinerja guru masih kurang.

Dari hasil uji statistik variabel pengembangan diri dengan loyalitas kinerja guru diperoleh nilai signifikan atau sig. (2-tailed) sebesar 0,877, karena nilai sig. (2-tailed) 0,877 < lebih besar dari 0,05 maka artinya tidak ada hubungan yang signifikan (bermakna) antara variabel pengembangan diri dangan loyalitas kinerja guru SDN 2 Margomulyo OKU Timur.

Hasil penelitian ini tidak sejalan dengan hasil penelitian yang dilakukan (Wicaksono, 2013), yang mengasilkan hubungan yang kuat antara pengembangan terhadap loyalitas kinerja guru di SMP Tri Mulya Semarang karena nilai $r$ hitung sebesar 0,799. Sama halnya dengan hasil penelitian A. Hanin, AK. Djaelani, dan MK. ABS, 2018), yang menghasilkan pengembangan karir dan pemberian insentif berpengaruh simultan terhadap loyalitas karyawan.

Sejalan dengan tantangan kehidupan global, peran dan tanggung jawab guru pada masa mendatang akan semakin kompleks, sehingga menuntut guru untuk senantiasa melakukan berbagai peningkatan penyesuaian penguasaan kompetensinya. Guru harus lebih dinamis dan kreatif dalam mengembangkan proses pembelajaran siswa.

Komunikasi intern antara guru yang efektif tentunya harus dikembangkan dengan baik karena iklim komunikasi yang kondusif antara pimpinan dengan bawahan atau sebaliknya, dan antar-sesama guru menjadi keniscayaan bagi penciptaan semangat kerja dalam kelompok. Menurut Hasibuan (2011), "Kesetiaan dicerminkan oleh kesediaan guru menjaga dan membela organisasi di dalam maupun di luar pekinerjaan dari rongrongan orang yang tidak bertanggung jawab."

Sekolah sebagai suatu organisasi juga membutuhkan suatu hubungan yang baik. Kerjasama ini dilakukan dengan orang-orang yang terlibat di dalamnya, seperti guru dengan guru, guru dengan kepala sekolah, guru dengan staf, guru dengan orang tua dan guru dengan siswa. Iklim kerjasama yang terjadi disekolah haruslah yang kondusif, karena suasana kondusif ini akan memaksimalkan potensi orang-orang yang terlibat di dalam organisasi sekolah yang pada akhirnya akan menciptakan pembelajaran yang efektif dan efisien untuk mencapai tujuan pendidikan. 


\section{PENUTUP}

\section{Kesimpulan}

Berdasarkan hasil penelitian, maka dapat disimpulkan tidak ada hubungan yang signifikan antara pengembangan diri dengan loyalitas kinerja guru SDN 2 Margomulyo OKU Timur karena diperoleh nilai signifikan atau sig. (2-tailed) sebesar 0,877 lebih besar dari 0,05 .

\section{Saran}

Dari hasil temuan penelitian ini, beberapa saran yang dapat penulis sampaikan sebagai berikut: pertama, kepada pihak sekolah agar senantiasa memberikan kesempatan dan motivasi kepada guru-gurunya untuk lebih banyak melakukan pengembangan diri sehingga akan dapat memberikan kontribusi yang positif terhadap pengembangan diri para guru dan sekolah ke arah yang lebih baik.

Kedua, bagi para guru, aspek pengembangan diri dan loyalitas agar menjadi faktor yang betul-betul diperhatikan dalam hal pencapaian karier sesuai dengan bidang ilmu yang dimilikinya.

Serta ketiga, bagi peneliti lain, kiranya pengembangan diri dan loyalitas kinerja adalah hal yang kompleks sekali dan dipengaruhi oleh banyak faktor. Masih banyak faktor lain yang perlu dikaji dan diteliti dalam pengaplikasian loyalitas kinerja guru.

\section{DAFTAR PUSTAKA}

A. Hanin, AK. Djaelani, dan MK. ABS. (2018). Pengaruh pengembangan karir dan pemberian insentif terhadap loyalitas karyawan radar bromo Probolinggo (jawa pos grup). E-Jurnal Riset Manajemen Prodi Manajemen Fakultas Ekonomi Unisma.

E. Mulyasa. (2005). Menjadi guru profesional. Bandung: PT. Remaja Rosda Karya

Gomes, Faustino Cardoso. (2006). Manajemen sumber daya manusia, Edisi 2 Cetakan 1, Andi Offset, Yogyakarta.

Hasibuan, Malayu. S. P. (2011). Manajemen sumber daya manusia (Edisi Revisi). Jakarta: Bumi Aksara.

Isjoni. (2007). Cooperative learning efektivitas pembelajaran kelompok. Bandung: Alfabeta.

Jusuf, Husein, Artikel (2010). Tingkatkan loyalitas guna peningkatan prestasi kerja dan karir.

Notoatmodjo, S. (2012). Metodologi penelitian kesehatan. Jakarta : PT Rineka Cipta

Singgih Santoso. (2014). Statistik non parametrik konsep dan aplikasi dengan SPSS. Jakarta: PT. Elex Media Komputindo.

Sudjana. (2005). Metoda Statistika. Bandung: Tarsito.

Sugiyono. (2017). metode penelitian kuantitatif, kualitatif, dan RED. Bandung: Alfabeta.

Wicaksono, P. (2013). Hubungan pengembangan karir dan pemberian insentif terhadap loyalitas kinerja guru. Jurnal Pendidikan Ekonomi IKIP Veteran SemarangVol. 01 No. 01, Juni 2013. 